Catalyst Papers in Press are peer-reviewed, accepted articles that have not yet been edited or formatted, but may be cited by DOI. The final version may contain substantive or nonsubstantive changes.

\title{
Adjusting Air-Assistance and Nozzle style for Optimized Airblast Sprayer Use in Eastern Washington Vineyards
}

\author{
Margaret L. McCoy, ${ }^{1}$ Gwen-Alyn Hoheisel, ${ }^{2}$ Lav R. Khot, ${ }^{3}$ \\ and Michelle M. Moyer ${ }^{1 *}$
}

${ }^{1}$ Department of Horticulture, Washington State University, Irrigated Agriculture Research and Extension Center, 24106 North Bunn Rd, Prosser, WA 99350; ${ }^{2}$ WSU Extension, Washington State University, 620 Market Street, Prosser, WA 99350; and ${ }^{3}$ Department of Biological Systems Engineering, Washington State University, Irrigated Agriculture Research and Extension Center, 24106 North Bunn Rd, Prosser, WA 99350.

*Corresponding author (Michelle.Moyer@wsu.edu)

Acknowledgments: This work was supported in part by the Washington State Grape and Wine Research Program, Washington State Wine Commission, Auction of Washington Wines, State Liter tax, and/or WSU Agriculture Research Center, the USDA National Institute of Food and Agriculture Predoctoral Fellowship [Grant \#12679191], and USDA National Institute of Food and Agriculture, Hatch project 1016563. The authors would like to thank WSU Irrigated Agriculture Research and Extension Center's farm management team for equipment technical support. The authors would also like to thank those who have provided assistance during the duration of this project, especially Maia Blom, Maria Mireles, Katherine East, Alexa McDaniel, Bernadette Gagnier, Charlotte Oliver, Rajeev Sinha, Rakesh Ranjan, Mark J. Schrader, and Anura Rathnayake-Mudiyanselage.

Manuscript submitted Apr 7, 2021, revised Jul 27, 2021, accepted Aug 6, 2021

This is an open access article distributed under the CC BY license

(https://creativecommons.org/licenses/by/4.0/).

By downloading and/or receiving this article, you agree to the Disclaimer of Warranties and Liability.

The full statement of the Disclaimers is available at https://www.asevcatalyst.org/content/proprietaryrights-notice-catalyst. If you do not agree to the Disclaimers, do not download and/or accept this article.

Goals: There are many ways to optimize an airblast sprayer for use in vineyards. Three techniques growers use include: 1) changing nozzle type, 2) reconfiguring or adjusting the nozzles, and 3) 
Catalyst Papers in Press are peer-reviewed, accepted articles that have not yet been edited or formatted, but may be cited by DOI. The final version may contain substantive or nonsubstantive changes.

adjusting the air-assistance to the droplets during an application. This study evaluated the effects of nozzle type and air-assistance use in airblast sprayers on canopy spray deposition and drift in a Washington wine grape vineyard that is trained to a modified vertical shoot positioning system.

\section{Key Findings:}

- The one-piece nozzle with air assistance showed consistently high total collected canopy deposition regardless of time of season (early or mid-season). However, drift was reduced when air-assistance was not used.

- The air induction nozzle had the greatest total collected canopy deposition when using airassistance during the early season, but had the greatest deposition mid-season without using air-assistance. Drift was reduced when air assistance was not used.

- Early in the growing season, maximum spray deposition in the fruiting zone of the canopy was achieved using air induction nozzles with air-assistance. However, if one adopted the use of air induction nozzle, without air, that would optimize fruiting zone spray deposition, while reducing captured aerial drift.

- Mid-growing season, maximum fruiting zone spray deposition without high drift was achieved using air induction nozzles without air-assistance.

Impact and Significance: An airblast sprayer optimized through changes in nozzle or use of airassistance can improve spray deposition into the canopy while minimizing drift. Growers can compare and adopt these drift-reduction techniques, i.e., using air induction nozzles and / or turning air-assistance off, to determine which are best suited for their farming practices. Such 
Catalyst Papers in Press are peer-reviewed, accepted articles that have not yet been edited or formatted, but may be cited by DOI. The final version may contain substantive or nonsubstantive changes. as well as reduce the possible negative impacts associated with off-target chemical deposition on humans and the environment.

Key words: airblast sprayer, air-assistance, air induction nozzle, drift reduction, one-piece nozzle,

57 spray deposition

Multiple sprayer styles are available for use in the application of foliar pesticide or fertilizer sprays across perennial cropping systems. For every \$1 USD spent on chemicals for pesticide applications, growers return-on investment is typically between \$3 to \$5 USD. ${ }^{1}$ Yet many producers of perennial crops currently use spray equipment and practices, such as the airblast sprayer, that may be inefficient or have human exposure risks due to drift, if used improperly. ${ }^{2}$ In Washington State, which is the second largest producer of wine grapes in the United States ${ }^{3}$, the axial fan airblast sprayer, hereafter referred to as "airblast sprayer", is still widely used in vineyards even though newer spray technologies are available. The airblast sprayer was originally engineered as a solution to the issue of achieving adequate chemical applications to tall orchard trees. ${ }^{4,5}$ The use of "air-assistance" was designed to propel spray droplets into large, bulbous canopies in nuts and fruit orchards, ${ }^{4,5}$ but can produce more drift. ${ }^{6}$ However, modern vineyard canopies are a fraction of the size of historical and current orchard trees leading to inappropriate volumes of air

71 from the sprayer in relation to the reduced volume of canopy. This mispairing has shown that 72 nearly half of the spray application from an airblast sprayer with hydraulic (exchangeable) nozzles 73 are lost to non-target deposition. ${ }^{7,8,9,10,11,12}$ Also, axial fan sprayers, even those with air 
Catalyst Papers in Press are peer-reviewed, accepted articles that have not yet been edited or formatted, but may be cited by DOI. The final version may contain substantive or nonsubstantive changes.

straighteners, produce a non-symmetrical air pattern which results in an uneven spray pattern of deposition in the canopy. ${ }^{13,14,15}$

Over the years, there has been a significant investment in research and extension to better adapt the airblast sprayer technology in various cropping systems to help overcome inherent flaws of the machinery. ${ }^{4,15,16,17,18}$ These have included the use of air straighteners, deflectors, smaller or larger fans, and improved low-drift nozzles. ${ }^{10}$ Moving beyond basic sprayer calibration to a focus on matching air volume to the canopy size or adjusting the number of open nozzle positions during an application, can generate a more efficient spray application. Simple changes in nozzle selection when operating sprayers, such as using nozzles with well-defined droplet size at set pressure outputs or low-drift nozzles, can reduce aerial drift while providing adequate spray deposition. ${ }^{19}$ Airblast sprayers have hydraulic (exchangeable) nozzles, meaning that the nozzles can be readily removed and replaced. For visualizations of different nozzle types, please see WSU Extension FS352E, "Common Interchangeable Nozzles for Perennial Crop Canopy Sprayers". ${ }^{20}$

Typically, airblast sprayers use disc-core type nozzles, which consist of an inner core or spinner plate and an outer disc. These nozzles produce a wide range of droplet diameter sizes $\left(D_{\mathrm{v} 0.1}\right.$ to $\mathrm{D}_{\mathrm{v} 0.9}$ of 100 to $\left.340 \mu \mathrm{m}\right) .^{21}$ Droplet size can also change because of chemical corrosion of the nozzle material over time with use ${ }^{15,21,22}$ or change in pressure. Modern improvement to the nozzle design includes the use of a single-piece, molded body nozzle that houses a ceramic orifice with a smaller droplet size range. This single body design also allows for easy identification of the nozzles as manufacturers color-code the nozzle body to indicate spray output (defined as gallons per minute $[\mathrm{GPM}]$ standard units, liters per minute [LPM] metric units). Another option is the air 
Catalyst Papers in Press are peer-reviewed, accepted articles that have not yet been edited or formatted, but may be cited by DOI. The final version may contain substantive or nonsubstantive changes.

induction nozzle. This nozzle design introduces air bubbles into spray droplets, creating enlarged droplets. Such larger droplets have more drag when traveling through the air, and therefore are less prone to drift. The air bubbles inside these droplets will allow it to "splatter" rather than rebounding or bouncing as they hit the target, ${ }^{22}$ which can occur with solid droplets produced by non-air induction nozzles

Though the airblast sprayer technology has not significantly changed over the years, that does not make it an obsolete technology to use in vineyards. With improved nozzle selection and

102 air assistance optimized to canopy size, airblast sprayers could be used more efficiently in 103 vineyards. Furthermore, with their adaptability they are a viable option for diversified farms with 104 multiple crops and canopy shapes. This project compared two axial fan airblast sprayer 105 optimization techniques with the goal of improving in canopy deposition and potential reduction in captured ground deposition and aerial drift when spraying typical early or mid-season grapevine

107 canopies grown under Eastern WA conditions, i.e., in vineyards trained to modified vertical shoot 108 positioning system, a common canopy training style in Washington. A Rears Manufacturing 109 Powerblast Pul-Tank airblast sprayer was used in this study with: 1) two different nozzle types, 110 i.e., a standard single-body hollow-cone nozzle and an air induction nozzle; and 2) the air111 assistance either on or off. 


\section{Major Observations and Interpretations}

\section{Early season spray deposition and drift.}

In the early season, there was an interactive effect between nozzle type and the use of air on the total amount of spray deposited in the canopy $(p=0.01)$. The air induction nozzle with airassistance configuration had the greatest total canopy spray deposition. The one-piece nozzle without air-assistance had the least (Fig. 1).

There was also an interactive effect between nozzle type and air-assistance on spray deposition in the upper canopy zone $(p<0.0001)$. Using air induction nozzles with air-assistance resulted in greater upper canopy spray deposition, however it was not significantly different than one-piece nozzles with air and AI with no air. Only the one-piece nozzles without air-assistance had significantly lower deposition in the upper canopy (Fig. 1). Spray deposition in the fruiting zone was influenced by the individual effects of the nozzle type $(p<0.0001)$ and air-assistance ( $p=0.0006)$ during spray applications. Using either air induction nozzles or air-assistance resulted in higher spray deposition in the fruiting zone.

We also looked at captured aerial drift at three different heights above the canopy, and at three different distances from the sprayed row. Aerial drift was collected in two to four rows away from the sprayer. There was an interactive effect between nozzle type and air-assistance on total captured aerial drift in the early season $(p<0.0001)$. Overall, applications with no air-assistance had the least drift, but in particular the one-piece nozzles without air-assistance had the least overall captured aerial drift. The greatest captured aerial drift occurred for either of the nozzles when using 
Catalyst Papers in Press are peer-reviewed, accepted articles that have not yet been edited or formatted, but may be cited by DOI. The final version may contain substantive or nonsubstantive changes. canopy did not influence the amount of captured aerial drift collected $(p=0.93)$, but distance from the sprayed row did $(p<0.0001)$. Furthermore, there was an interactive effect between nozzle type and use of air-assistance for the amount of captured aerial drift collected from the sprayer at row two $(p=0.004)$, row three $(p=0.0008)$, and row four $(p<0.0001)$ from the sprayer. Applications made with one-piece nozzles without air-assistance had the least captured aerial drift in all of the rows; air induction nozzles with air-assistance had the greatest captured aerial drift in rows two and three from the sprayer, and one-piece with air-assistance had the greatest drift into row four

141 from the sprayer (Fig. 2). This is because smaller droplets in wind (or air) can move further than larger droplets in the absence of wind.

Total ground deposition was influenced by an interactive effect between nozzle type and 144 air-assistance $(p<0.0001)$. Using the one-piece nozzle without air-assistance resulted in the least 145 total ground deposition, whereas using air induction nozzle without air-assistance had the greatest total deposition to the ground (Fig. 3). There was also an interactive effect between nozzle type 147 and the use of air-assistance on ground deposition collected one row $(p<0.0001)$, two rows $148(p=0.002)$, and three rows $(p=0.002)$ from the sprayer. When air-assistance is used with larger 149 droplets, such as with air induction nozzles, they are blown farther, thus resulting in more ground 150 deposition in rows two and three from the sprayed row. These droplets were blown past the 151 collectors in the first row of ground deposition collectors and landed in the farther rows because 152 of the air pushing the larger droplets causing a larger falling arc. 
Catalyst Papers in Press are peer-reviewed, accepted articles that have not yet been edited or formatted, but may be cited by DOI. The final version may contain substantive or nonsubstantive changes.

doi: 10.5344/catalyst.2021.21001

Even though the sprayer was optimized for the canopy size by using only nozzles directed into the canopy, droplets can still go past the intended target during an application. Droplet size can significantly influence drift; small droplets can drift upward and farther downwind. ${ }^{4,11}$ In this study, the one-piece nozzle produced smaller droplets than the air induction nozzle, so one would expect to see the most captured aerial drift with one-piece nozzles, but that was not always the case as there was an interaction with air. Despite droplet size differences more aerial drift was captured when air was used. This emphasizes the importance of matching air volume and direction to the canopy being sprayed when optimizing a sprayer. These results seem intuitive given the small size of the vine canopy during the early season (average height of $48.6 \mathrm{~cm}$ [19.2 inches] and width of $41.8 \mathrm{~cm}$ [16.5 inches ]; average density of $724 \mathrm{~m}^{3}$ per hectare [10,347 $\mathrm{ft}^{3}$ per acre]). Smaller, sparse vine canopies would have increased blow through due to less foliage to capture spray droplets. This canopy structure also influences the ground deposition patterns seen with air induction nozzles. The droplets are larger, less prone to captured aerial drift than the smaller droplets, but clearly resulted in more ground deposition because the canopy is sparse.

168 air induction nozzle with air-assistance resulted in the greatest spray deposition in the canopy 169 during pre-bloom spray applications, but the one-piece nozzle without air-assistance had the least 170 aerial drift captured during this time. More specifically, the highest captured deposition in the 171 fruiting zone, the economically important zone in a vine canopy, was seen with air induction 172 nozzles and the use of air. When considering the factors of deposition and aerial drift, the use of 173 air induction nozzles without air in this early season, may provide adequate spray coverage while 
Catalyst Papers in Press are peer-reviewed, accepted articles that have not yet been edited or formatted, but may be cited by $\mathrm{DO}$. The final version may contain substantive or nonsubstantive changes.

174

175

176

177

178

179

180

181

182

183

reducing captured aerial drift. It is important to note that ground deposition early season was higher when using this nozzle and air combination, but overall ground deposition was low in this study, ranging from 15 to $170 \mathrm{X}$ less than what was captured in the canopy. Since ground deposition is considered to be less of an environmental and human health risk, and that amount collected from the air induction sprayer configurations, with or without air assistance, is so minimal the optimal choice between these two configurations may not be practically different. Additionally, we only tested two air configurations (on or off) but in future vineyard applications the fan could be slowed further to produce lower air volume and determine if that configuration could result in similar canopy spray deposition with less ground deposition.

\section{Mid-season spray deposition and drift.}

The vine canopy at this time had an average height of $77.2 \mathrm{~cm}$ (30.4 inches) and width of $81.3 \mathrm{~cm}$ (32.1 inches) over all collection dates. During mid-season spray applications, the total spray deposited to the canopy was influenced by the combined effects of nozzle choice and airassistance $(p=0.0005)$. There was no statistical difference in total collected canopy deposition when using air induction nozzles without air-assistance or one-piece nozzles with or without airassistance. Air induction nozzles with air-assistance had the least total collected canopy deposition (Fig. 4). More specifically though when considering canopy spray deposition by zone, deposition in the upper canopy was influenced by the individual effect of nozzle type $(p=0.0006)$, but not by air-assistance (Fig. 4). Applications made using configurations with one-piece nozzles resulted in greater collected spray deposition to the upper canopy than applications using the air induction nozzles (Fig. 4). There was an interactive effect of nozzle type and air-assistance on collected 
Catalyst Papers in Press are peer-reviewed, accepted articles that have not yet been edited or formatted, but may be cited by DOI. The final version may contain substantive or nonsubstantive changes.

doi: 10.5344/catalyst.2021.21001

spray deposition in the fruiting zone $(p<0.0001)$. Applications made with the air induction nozzles without air-assistance resulted in greater canopy deposition, whereas applications using the onepiece nozzles without air-assistance had the least fruiting zone spray deposition (Fig. 4).

In the mid-season, total captured aerial drift was influenced by the interactive effect between nozzle type and air-assistance $(p<0.0001)$. The air induction nozzles with air-assistance had the greatest drift; the one-piece and air induction nozzle without air-assistance had the least amount of captured aerial drift (Fig. 5). The height above the canopy did not influence total captured aerial drift $(p=0.54$, but distance from the sprayed row did $(p<0.0001)$. In the second row from the sprayer, there was an interactive effect between nozzle type and air-assistance $(p<0.0001)$, however, the overall pattern is that nozzles used with air-assist resulted in significantly more drift. One-piece and air induction nozzles without air-assistance configurations resulted in 59 to over 500X less captured aerial drift than one-piece and air induction with air-assistance (Fig. 5). Captured aerial drift in rows three and four from the sprayer was only influenced by airassistance $(p<0.0001)$, with less drift occurring without air-assistance (Fig. 5).

Total spray drifting to the vineyard ground during the mid-season was also influenced by the interactive effect between nozzle type and air-assistance $(p<0.0001)$. One-piece and air induction nozzle without air-assistance had the least ground deposition collected; the air induction nozzle with air-assistance had the greatest ground deposition, though it was still relatively low (Fig. 6). There was also an interactive effect between nozzle and air-assistance on the amount of ground deposition collected in row one and two from the sprayed row ( $<<0.0001$, respectively). Air induction and one-piece nozzles without air-assistance had the least ground deposition in the 
Catalyst Papers in Press are peer-reviewed, accepted articles that have not yet been edited or formatted, but may be cited by DOI. The final version may contain substantive or nonsubstantive changes.

rows adjacent to the sprayer; air induction with air-assistance had the greatest ground deposition in these rows. Ground deposition was significantly increased in in row three when air-assistance was used $(\mathrm{p}<0.0001)$ (Fig. 6). Overall ground deposition during the mid-season applications were reduced when the sprayer was operated without air-assistance, which is anticipated since added air movement from the sprayer would likely increase the distance droplets would travel away from the sprayed row.

In the mid-season, the best sprayer configuration for maximizing spray deposition to the canopy, while minimizing captured aerial drift and ground deposition was the air induction nozzle without air-assistance. However, captured aerial drift in the mid-season was much lower than in the early-season, suggesting that the primary focus for sprayer configuration should be on optimizing canopy deposition, rather than on drift reduction - assuming the sprayer air volume and direction is appropriately matched to the canopy size and density. As such, the configuration of a one-piece nozzle with air-assistance may be preferential, particularly in larger canopies, as it has equally high canopy and fruit zone spray deposition as the air induction nozzle without airassistance. Although not directly measured in this experiment, the smaller droplets may have a greater likelihood of penetrating into tight clusters.

Airblast sprayers often have a rotating nozzle body that can accommodate two or more nozzles at the same location. If air induction nozzles are used in early season, they can be in one side of the nozzle body, while a one-piece is installed on the other for later season. If other management decisions require only one-type of nozzle to be used, the one-piece nozzle early season did have comparable coverage, although slightly less, to air induction. However, excess 
Catalyst Papers in Press are peer-reviewed, accepted articles that have not yet been edited or formatted, but may be cited by $\mathrm{DO}$. The final version may contain substantive or nonsubstantive changes.

wind and high temperatures during applications should be avoided to not exacerbate the higher captured aerial drift. In regions with high winds or rural-urban interface, the constraints of using a single nozzle could be achieved with the air induction nozzles without air-assistance as there was comparable coverage to one-piece nozzles and even more deposition in the fruit zone with less drift.

\section{Broader Impact}

There are many different approaches to optimize an airblast sprayer for vineyard use; two such techniques are nozzle selection, and the choice on the use of air-assistance. With applicable information on how these approaches may impact deposition and drift within a vineyard, growers can make more informed decisions on which approaches to apply at their sites. In addition, this information can also be used to help them determine if they are in compliance with local and national regulations related to spray drift, particularly as it relates to application exclusion zones within the farm business' boundaries. ${ }^{23}$ Application exclusion zones are determined by sprayer type, and airblast has the largest zone, i.e., $30.5 \mathrm{~m}(100 \mathrm{ft})$ in every direction from the sprayer. This US regulation requires growers to update their practices to adjust spray applications to keep drift within these zones. As the canopy grows and changes throughout the season, the sprayer configuration should adapt with the canopy to keep droplets directed into the canopy. Growers often use air to compensate for the increasing size in a grape canopy, but the information presented here shows this may not be necessary to achieve adequate in canopy deposition. Without blowing through the canopy the droplets have an opportunity to swirl within the leaf space and be deposited 
type used at different times of the season with large canopy differences can change deposition and drift, as seen in comparing spray configuration using air induction nozzles which had the greatest ground deposition in the early season and the least in mid-season collections. Steps to advance this research would be to include biological efficacy data of chemical applications..

\section{Experiment Design}

\section{General experimental design.}

A summary of sprayer operation information, including dates of sprays, specific vine

267 growth stage at the time of application, and sprayer-specific operating metrics are presented in

268 Table 1. Evaluations for each sprayer setup and timing were temporally repeated four times. The 269 early season evaluations were conducted on day of the year (DOY) 143 and 144 in 2019, and DOY 140 and 147 in 2020. Mid-season evaluations were conducted on DOY 194 and 198 in 2018, and

271 DOY 192 and 196 in 2020.

273 Site and equipment descriptions. 
Catalyst Papers in Press are peer-reviewed, accepted articles that have not yet been edited or formatted, but may be cited by $\mathrm{DO}$. The final version may contain substantive or nonsubstantive changes.

277

278

279

280

281

282

283

284

285

286

287

288

289

290

291

292

293

294

295

296

297

rooted Vitis vinifera 'Chardonnay' on a 1.8 by $3.1 \mathrm{~m}$ vine by row spacing and trained to a modified vertical shoot positioned (VSP) system with a set of single catchwires at approximately $34 \mathrm{~cm}$ above the cordon, and a structural trellis wire at approximately $60 \mathrm{~cm}$ above the cordon. Industry standard irrigation and pest management programs were followed.

Sprayer description. The Powerblast Pul-Tank airblast (Model 4S), a single row, axial fan sprayer, manufactured by Rears Manufacturing (Coburg, OR, USA) was used in this study (Fig. 7). It was operated by a John Deere 2355N in 2018 and a New Holland T4.75V in 2019 and 2020. Per industry standard, a rate controller was not used. The sprayer had a $0.84 \mathrm{~m}$ fan at $20^{\circ}$ pitch and was operated at 90 psi (6.2 bar) for all years of the experiment. Each side of the sprayer had 12 available nozzles with individual manual valve controls. Early season data was collected with three nozzles open per side during applications, and mid-season data was collected with four nozzles open per side during applications (Table 1). We increased the number of nozzles used in our later season applications to accommodate the larger and higher canopy growth. Height of nozzles above the ground level were: nozzle $1-100 \mathrm{~cm}$; nozzle $2-116 \mathrm{~cm}$; nozzle $3-125 \mathrm{~cm}$; and nozzle 4 $133 \mathrm{~cm}$.

Nozzle description and application approach. Two types of hollow cone pattern nozzles were used in these trials, the Teejet ${ }^{\circledR}$ Conejet $^{\circledR}$ VisiFlo $^{\circledR}$ (one-piece) and Teejet $^{\circledR}$ air induction. Nozzle model information can be found in Table 1. Each treated section of vineyard was sprayed on both sides of the canopy. With the one-piece nozzle, the eastern side of the canopy was sprayed on the first pass, and the western side of the canopy was sprayed on the second pass. For the air induction nozzle, the western side of the canopy was treated on the first pass, and the eastern side 
Catalyst Papers in Press are peer-reviewed, accepted articles that have not yet been edited or formatted, but may be cited by $\mathrm{DO}$. The final version may contain substantive or nonsubstantive changes.

of the canopy was treated on the second pass. Since axial fans have a lopsided air volume output $^{13,15}$ on either side it is important to note how the applications were made in case a systematic difference is uncovered through sample analysis. No such difference was found in the sample data collected, but to ensure that this inherent machinery characteristic was accounted for both sides of the canopy were averaged across canopy zones.

Travel speed calculations. The tractor speed, calculated before each spray trial application, was timed over a set-length course $(91.44 \mathrm{~m})$ and calculated to kilometer per hour $(\mathrm{km} / \mathrm{h})$. During speed calculation trials, the tractor was operated at the same settings during an experimental application with the power take-off (PTO) engaged at the rotations per minute (RPM) of the intended application and with a full sprayer tank (Table 1). The spray volume was adjusted to account for changes in canopy size through the growing season.

\section{Weather and canopy measurements.}

Environmental parameters including wind speed $(\mathrm{km} / \mathrm{h})$, wind direction $\left(^{\circ}\right)$, relative humidity $(\mathrm{RH}, \%)$, and air temperature $\left({ }^{\circ} \mathrm{C}\right)$ were collected continuously during spray applications. An all-in-one weather station (ATMOS 41, METER Group Inc., Pullman, WA, USA) connected to a data logger (CR1000, Campbell Scientific, Logan, UT, USA) was used to acquire environmental data at $0.02 \mathrm{~Hz}$. The weather station was mounted approximately $3 \mathrm{~m}$ above ground level. On days that the all-in-one ATMOS 41 weather station did not record weather data, the corresponding weather data was pulled from Washington State University's AgWeatherNet (weather.wsu.edu) weather station network for "Prosser NE". The AgWeatherNet "Prosser NE" 
Catalyst Papers in Press are peer-reviewed, accepted articles that have not yet been edited or formatted, but may be cited by $\mathrm{DO}$. The final version may contain substantive or nonsubstantive changes.

station was used early season DOY 143 in 2019 for the first sprayer set up and on DOY 147 in 2020 during applications. This station is located within $1 \mathrm{~km}(0.6$ miles $)$ of the site, and has an elevation difference of less than $50 \mathrm{~m}(165 \mathrm{ft})$. Collected environmental parameters conformed to ISO standards, i.e., $\pm 25 \%$ deviation for wind speed, $\pm 10 \%$ deviation for $\mathrm{RH}, \pm 5 \%$ deviation for temperature, and $\pm 10 \%$ deviation for wind direction between the tests being compared, for all spray trials in early and mid-season, except wind direction. ${ }^{25}$ Median wind direction for all trials came from a westerly direction (west, $270^{\circ}$ ), but did not conform to the $\mathrm{ISO}^{25}$ standard requirement of no more than $30 \%$ of the collected data points being greater than $45^{\circ}$ from the perpendicular spray track (early season: 55\%; mid-season: 37\%). All environmental data recorded during experiments can be found in Tables 2 and 3.

Canopy measurements were taken after each application was made in a $3 \mathrm{~m}$ section of vines not in a data row. Five canopy height measurements, from cordon to furthest vegetation at that particular section of vine, and five canopy width measurements, between the furthest vegetation on either side at that particular section of vine, were recorded per $3 \mathrm{~m}$ section of vines. These measurements were collected in two different places in the vineyard, and then averaged to determine vine-row-volume of the canopy at time of application.

\section{Spray deposition and drift collection and processing.}

The spray deposition and drift collection and processing methods described below were similar to those done by McCoy et al. ${ }^{26}$ with a few modifications as indicated below. As with that previous study, a fluorescent tracer Keystone $^{\mathrm{TM}}$ Pyranine 10G; Milliken ${ }^{\mathrm{TM}}$; Spartanburg, SC, 
Catalyst Papers in Press are peer-reviewed, accepted articles that have not yet been edited or formatted, but may be cited by $\mathrm{DO}$. The final version may contain substantive or nonsubstantive changes.

USA) was used as a tracer dye for collecting spray droplet canopy deposition, captured aerial drift, and ground deposition on $5 \times 5 \mathrm{~cm}$ plastic cards. Tracer concentrations were used to normalize collected data across spray dates using a pre- and post-tank sample.

Canopy spray deposition - Experimental design. Collection of canopy deposition was made possible using 15 PVC pipe poles down a single row to hold the plastic cards within the zones of interest (Fig. 8A). Canopy deposition on the plastic cards had five zones per pole ${ }^{25}$, but in data analysis, we combined these zones to represent the "upper canopy" (east, west, and middle of the upper canopy; $n=45$ ), and the fruiting zone (east and west of canopy fruit zone; $n=30$ ). Distance between plastic cards in the upper canopy and fruiting zone was approximately $17 \mathrm{~cm}$. Captured aerial drift and ground deposition - Experimental design. Captured aerial drift poles, also constructed of PVC (Fig. 8B), were placed in rows two to four downwind from the sprayed row (Fig. 8D) and collected drift at 0.3, 0.6, and $0.9 \mathrm{~m}$ above the canopy. Ground deposition was collected using wooden blocks $(10 \times 17 \mathrm{~cm})$, placed in the middle of the interrow (Fig. 8C), with plastic cards affixed under a rubber band. Each treatment replicate consisted of three drift poles in $2018(\mathrm{n}=3)$ and nine drift poles in 2019 and $2020(\mathrm{n}=9)$. Ground deposition blocks were placed in line with the drift poles and the same sampling pattern as captured aerial drift ( $n=3$ in 2018 and $n=9$ in 2019 and 2020). Captured aerial drift and ground deposition data was increased between 2018 and 2019 to ensure enough sample size based upon previous data collection with other field trials. ${ }^{26}$ The captured aerial drift and ground deposition were collected from the center vine of each repetition in $2018(n=3)$ and the center three vines of each repetition in 2019 and $2020(\mathrm{n}=9)$. 
Catalyst Papers in Press are peer-reviewed, accepted articles that have not yet been edited or formatted, but may be cited by DOI. The final version may contain substantive or nonsubstantive changes. temperature, samples can be stored up to 90 days with minimal deterioration. ${ }^{27}$ sample of the solution, with a reading in parts per billion $(\mu \mathrm{g} / \mathrm{L})$, via a borosilicate class cuvette. reanalyzed. Each sample reading was corrected using a calibration curve produced from tracer

372 standards made from each chemical lot of tracer specific to a trial. ${ }^{28}$

373 Statistical analysis. across all application days to allow for comparison among sprayer configurations. Deposition drift

377 their interaction as fixed effects, and experimental repetition (DOY) as a random effect. In the case 
Catalyst Papers in Press are peer-reviewed, accepted articles that have not yet been edited or formatted, but may be cited by DOI. The final version may contain substantive or nonsubstantive changes.

sprayer was also evaluated as a fixed effect. Post-hoc means separation was done using Tukey's honest significant difference, with $\alpha=0.05$ as a significance threshold (JMP; ver. 15.0.0, SAS Institute Inc., Cary, NC, USA).

\section{References and Endnotes}

1. Pimentel D, McLaughlin L, Zepp A, Lakitan B, Kraus T, Kleinman P, Vancini F, Roach WJ, Graap E, Keeton WS and Selig G. 2008. Environmental and economic impacts of reducing U.S. agricultural pesticide use. In The Pesticide Question, pp. 223-278. Springer USA.

2. Kasner EJ, Fenske RA, Hoheisel GA, Galvin K, Blanco MN, Seto EYW and Yost MG. 2018. Spray drift from a conventional axial fan airblast sprayer in a modern orchard work environment. Ann Work Expo Heal 62:1134-1146.

3. NASS. 2018. Noncitrus Fruits and Nuts 2017 Summary. United States Department of Agriculture National Agriculture Statistics Service. http://usda.mannlib.cornell.edu/usda/current/NoncFruiNu/NoncFruiNu-06-26-2018.pdf. Accessed 6 August 2018.

4. Fox RD, Derksen RC, Zhu H, Brazee RD and Svensson SA. 2008. A history of air-blast sprayer development and future prospects. Trans. ASAE, 51:405-410.

5. Rose GJ. 1963. Crop Protection. Chemical Publishing Co., Inc., New York, NY.

6. Cook BK, Hislop EC, Herrington PJ, Western NM and Humpherson-Jones F. 1990. Airassisted spraying of arable crops, in relation to deposition, drift and pesticide performance. Crop Prot 9: 303-311.

7. Raisigl U, Felber H, Siegfried W and Krebs C. 1991. Comparison of different mist blowers and volume rates for orchard spraying. In BCPC Monograph 46:185-196. British Crop Protection Council, Farnham, Surrey, United Kingdom.

8. Vercruysse F, Steurbaut W, Drieghe S and Dejonckheere W. 1999. Off target ground deposits from spraying a semi-dwarf orchard. Crop Prot 18:565-570.

9. Brown DL, Giles DK, Oliver MN and Klassen P. 2008. Targeted spray technology to reduce 
Catalyst Papers in Press are peer-reviewed, accepted articles that have not yet been edited or formatted, but may be cited by DOI. The final version may contain substantive or nonsubstantive changes.

doi: 10.5344/catalyst.2021.21001

pesticide in runoff from dormant orchards. Crop Prot 27:545-552.

10. Landers AJ. 2010. Effective vineyard spraying: A practical guide for growers. Effective Spraying. Ithaca, NY, USA.

11. Bonds JAS, Leggett M. 2015. A literature review of downwind drift from airblast sprayers: Development of standard methodologies and a drift database. Trans ASABE 58: 1471-1477.

12. Garcerá C, Moltó E and Chueca P. 2017. Spray pesticide applications in Mediterranean citrus orchards: Canopy deposition and off-target losses. Sci Total Environ 599-600, 1344-1362.

13. Bahlol H, Chandel A, Hoheisel G, and Khot LR. 2020. Developing understanding on orchard sprayer air-assists and volume output patterns using smart spray analytical system. Crop Prot 127: 104977.

14. Rathnayake AP, Chandel A, Schrader M, Hoheisel G and Khot LR. 2021. Spray patterns and perceptive canopy interaction assessment of commercial airblast sprayers used in Pacific Northwest perennial specialty crop production. Comput Electron Agric 184:106097.

15. Deveau J, Ledebuhr M and Manketelow D. 2021. Airblast 101: Your guide to effective and efficient spraying. https://sprayers101.com/airblast101/. Accessed 7 January 2021

16. Shelton D and VonBargen K. 1977. CC279 Gear up -- throttle down. Historical materials from University of Nebraska-Lincoln Extension. 3126. Online: http://digitalcommons.unl.edu/extensionhist/3126. Accessed 24 April 2018.

17. Balsari P and Marucco P. 2004. Sprayer adjustment and vine canopy parameters affecting spray drift: the Italian experience. In Int Conf on Pesticide Application for Drift Management, pp: 109-115. Waikoloa, Hawaii.

18. Salcedo R, Garcerá C, Granell R, Moltó E and Chueca P. 2015. Description of the airflow produced by an air-assisted sprayer during pesticide applications to citrus. Spanish J Agric. Res 13:e0208.

19. Derksen RC, Zhu H, Fox RD, Brazee RD and Krause CR. 2007. Coverage and drift produced by air induction and conventional hydraulic nozzles used for orchard applications. Trans 
ASABE. 50:1493-1501.

20. McCoy M, Moyer MM and Hoheisel G. 2020. Common interchangeable nozzles for perennial crop canopy sprayers. Washington State University Extension Publication \#FS352E

21. ASABE. 2009. ASABE S572.1 Droplet size classification. Am Soc Agric Biol Eng. [Online]: https://cdn2.hubspot.net/hub/95784/file-32015844pdf/docs/asabe_s572.1_droplet_size_classification.pdf. Accessed 18 June 2020.

22. Deveau J. 2019. Sprayers 101: How airblast spray droplets behave (or misbehave). https://sprayers101.com/misbehave/. Accessed 8 October 2020.

23. 40 CFR $\S 170.405$ - Entry restrictions associated with pesticide applications. United States Code of Federal Regulations. https://www.govinfo.gov/content/pkg/CFR-2019-title40vol26/xml/CFR-2019-title40-vol26-sec170-405.xml. Accessed 22 April 2020.

24. Panneton B, Lacasse B and Piché M. 2005. Effect of air-jet configuration on spray coverage in vineyards. Biosyst Eng 90:173-184.

25. ISO 22522:2007. 2007. ISO 22522: Crop protection equipment — Field measurement of spray distribution in tree and bush crops.

26. McCoy M, Hoheisel GA, Khot LR and Moyer MM. 2021. Assessment of three over-the-row sprayer technologies in eastern Washington wineyards. Am J Enol Vitic 72:209-216.

27. Nairn JJ and Forster WA. 2015. Photostability of pyranine and suitability as a spray drift tracer. New Zeal Plant Prot 68:32-37.

28. Khot LR, Ehsani R, Albrigo G, Larbi PA, Landers A, Campoy J and Wellington C. 2012. Air-assisted sprayer adapted for precision horticulture: Spray patterns and deposition assessments in small-sized citrus canopies. Biosyst Eng 113:76-85. 


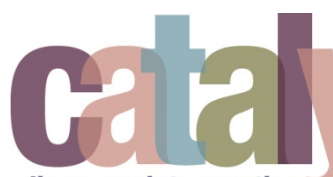

discovery into practice
Catalyst Papers in Press are peer-reviewed, accepted articles that have not yet been edited or formatted, but may be cited by DOI. The final version may contain substantive or nonsubstantive changes.

doi: 10.5344/catalyst.2021.21001

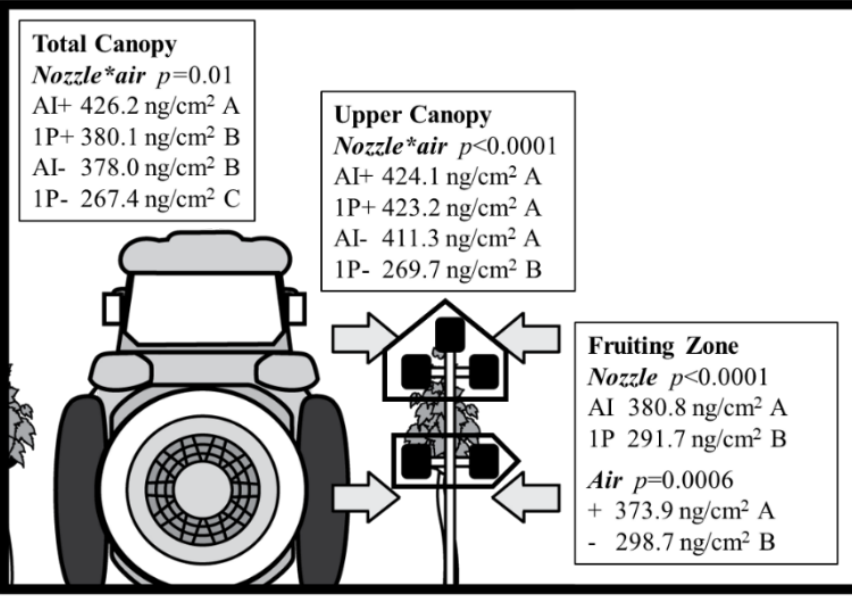

Figure 1. Early season total canopy, upper and fruiting zone canopy deposition for Rears Manufacturing Pul Blast airblast sprayer during trials in 2019 and 2020. Arrows indicate that spray occurred on both sides of the canopy. Lettering after reported average deposition (nanograms per centimeter ${ }^{2}, \mathrm{ng} / \mathrm{cm}^{2}$ ) indicate significant difference in means using Tukey's HSD at $\alpha=0.05$ within each canopy zone. AI $=$ air induction nozzle; $1 \mathrm{P}=$ one-piece nozzle; $+=$ with air-assistance; $-=$ without air-assistance Only effects that were statistically significant are shown.

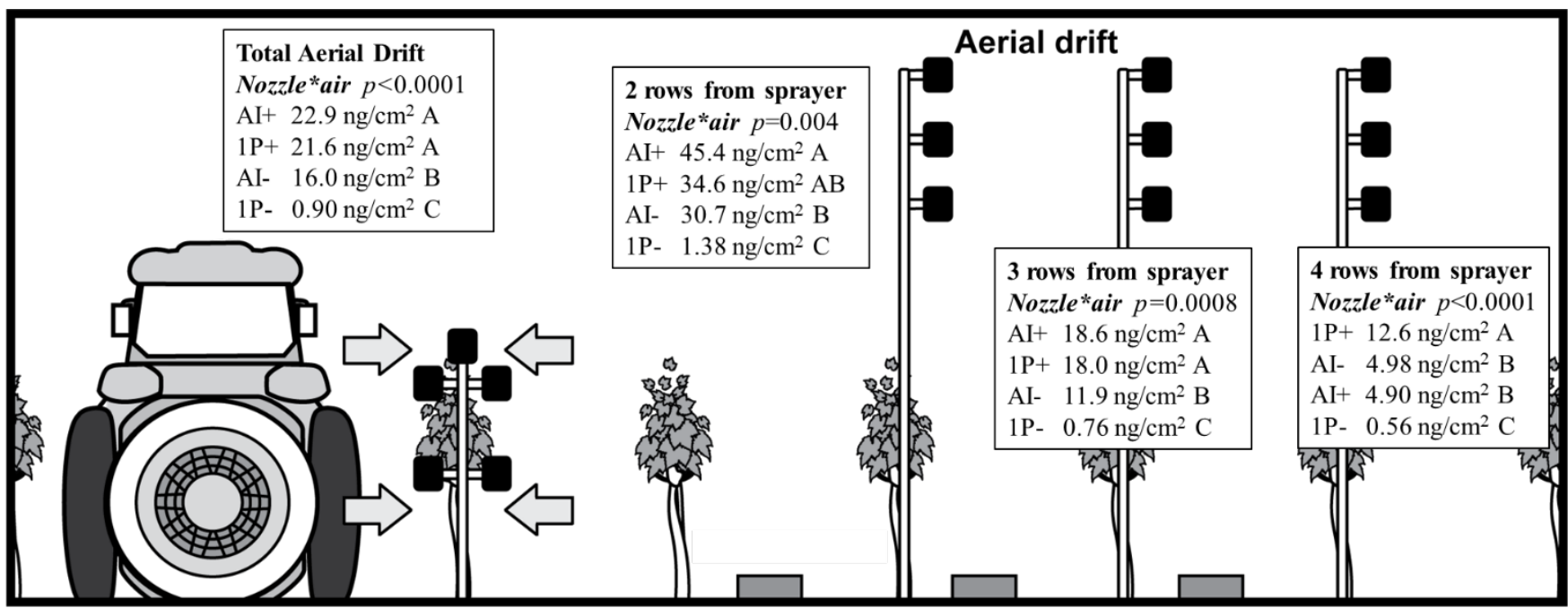

Figure 2. Early season total captured aerial drift and captured aerial drift in rows two, three, and for from the sprayed row for Rears Manufacturing Pul Blast airblast sprayer during trials in 2019 and 2020. Arrows indicate that spray occurred on both sides of the canopy. Lettering after reported average deposition (nanograms per centimeter ${ }^{2}, \mathrm{ng} / \mathrm{cm}^{2}$ ) indicate significant difference in means using Tukey's HSD at $\alpha=0.05$ within each canopy zone. $\mathrm{AI}=$ air induction nozzle; $1 \mathrm{P}=$ one-piece nozzle; $+=$ with airassistance; - = without air-assistance. Only effects that were statistically significant are shown. 


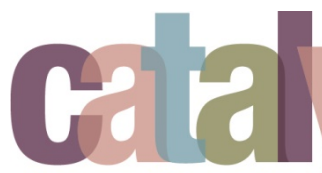

discovery into practice
Catalyst Papers in Press are peer-reviewed, accepted articles that have not yet been edited or formatted, but may be cited by DOI. The final version may contain substantive or nonsubstantive changes.

doi: 10.5344/catalyst.2021.21001

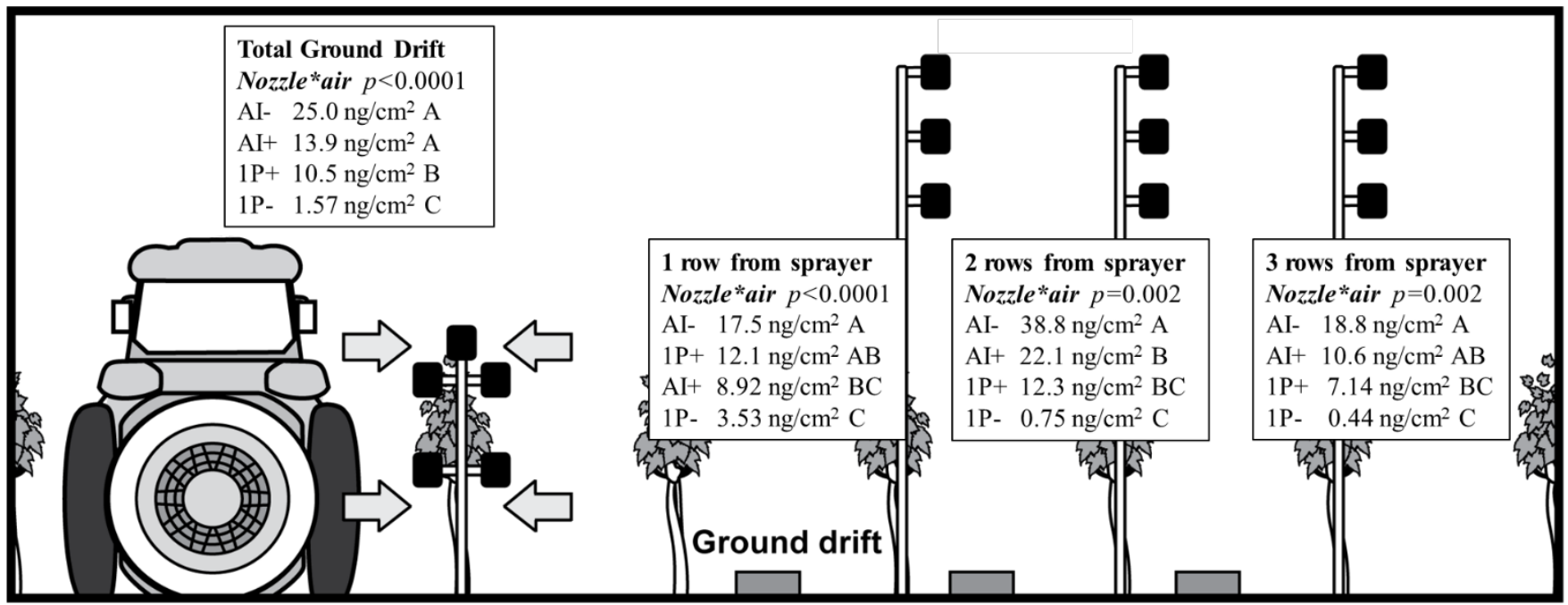

Figure 3. Early season ground deposition collected in rows one, two, and three from the sprayed row for Rears Manufacturing Pul Blast airblast sprayer during trials in 2019 and 2020. Arrows indicate that spray occurred on both sides of the canopy. Lettering after reported average deposition (nanograms per centimeter ${ }^{2}, \mathrm{ng} / \mathrm{cm}^{2}$ ) indicate significant difference in means using Tukey's HSD at $\alpha=0.05$ within each canopy zone. $\mathrm{AI}=$ air induction nozzle; $1 \mathrm{P}=$ one-piece nozzle; $+=$ with air-assistance; $-=$ without airassistance. Only effects that were statistically significant are shown.

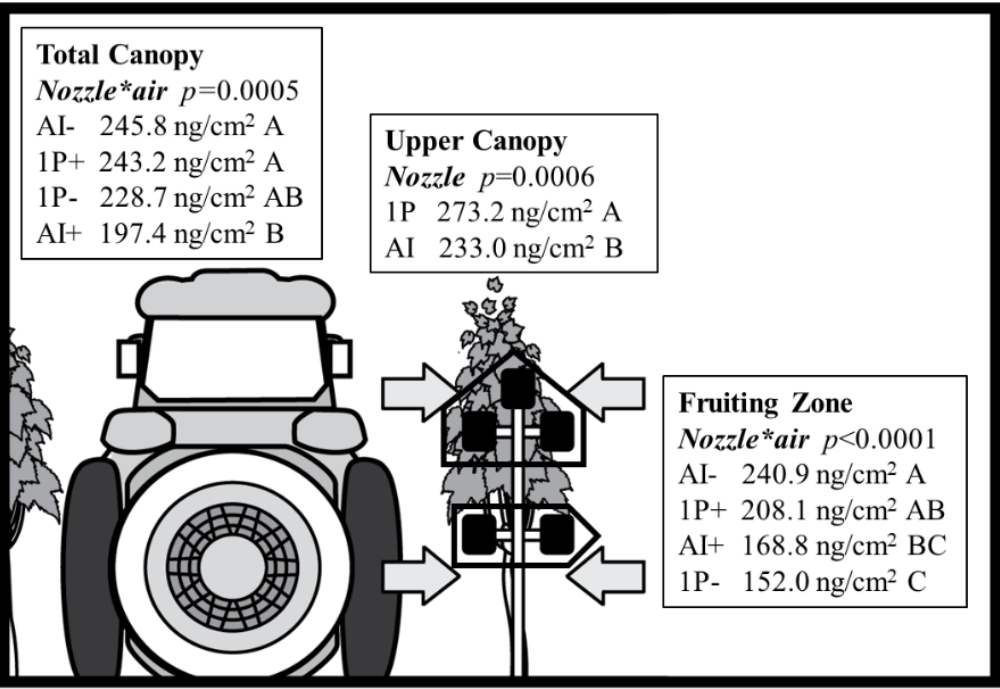

Figure 4. Mid-season total canopy, upper and fruiting zone canopy deposition for Rears Manufacturing Pul Blast airblast sprayer during trials in 2018 and 2020. Arrows indicate that spray occurred on both sides of the canopy. Lettering after reported average deposition (nanograms per centimeter ${ }^{2}, \mathrm{ng} / \mathrm{cm}^{2}$ ) indicate significant difference in means using Tukey's HSD at $\alpha=0.05$ within each canopy zone. AI $=$ air induction nozzle; $1 \mathrm{P}=$ one-piece nozzle; $+=$ with air-assistance; $-=$ without air-assistance. Only effects that were statistically significant are shown. 
Catalyst Papers in Press are peer-reviewed, accepted articles that have not yet been edited or formatted, but may be cited by DOI. The final version may contain substantive or nonsubstantive changes.

doi: $10.5344 /$ catalyst.2021.21001

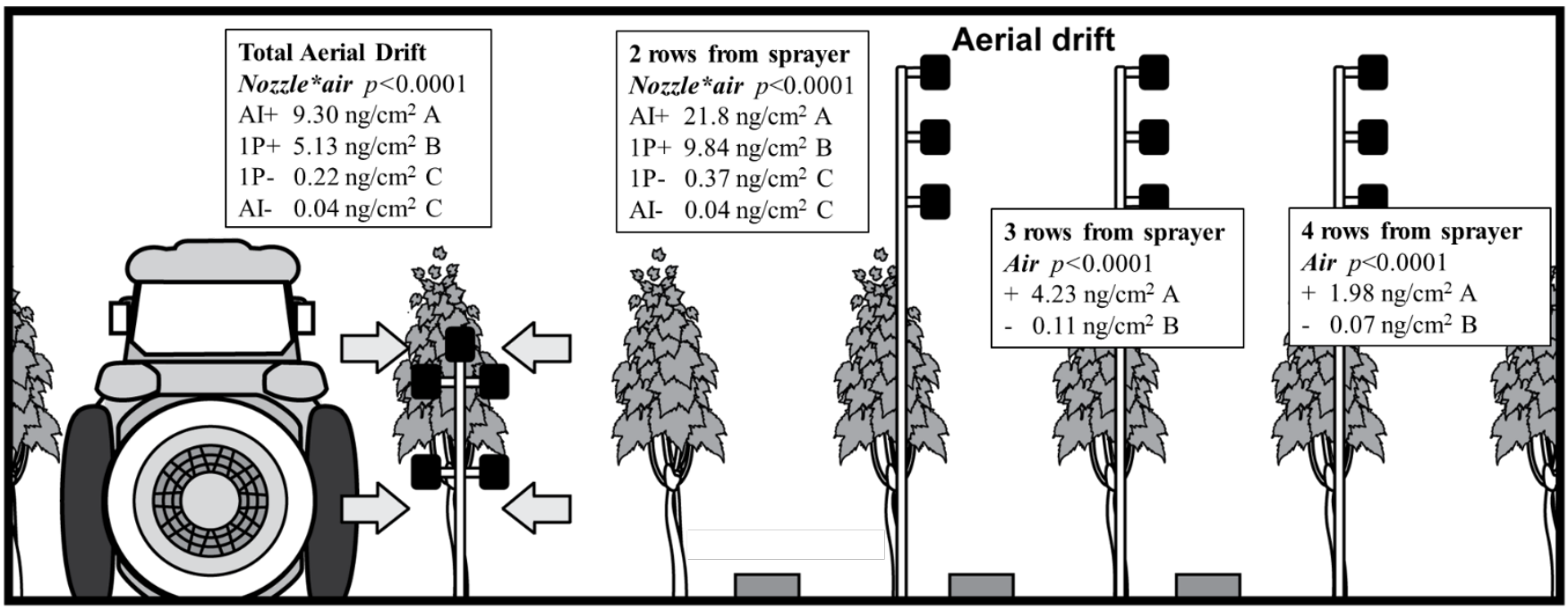

Figure 5. Mid-season total captured aerial drift and captured aerial drift in rows two, three, and four from the sprayed row for Rears Manufacturing Pul Blast airblast sprayer during trials in 2018 and 2020. Arrows indicate that spray occurred on both sides of the canopy. Lettering after reported average deposition (nanograms per centimeter ${ }^{2}, \mathrm{ng} / \mathrm{cm}^{2}$ ) indicate significant difference in means using Tukey's HSD at $\alpha=0.05$ within each canopy zone. $\mathrm{AI}=$ air induction nozzle; $1 \mathrm{P}=$ one-piece nozzle; $+=$ with airassistance; - = without air-assistance. Only effects that were statistically significant are shown.
Total Aerial Drift

$\mathrm{AI}+9.30 \mathrm{ng} / \mathrm{cm}^{2} \mathrm{~A}$

$1 \mathrm{P}+5.13 \mathrm{ng} / \mathrm{cm}^{2} \mathrm{~B}$

$\sqrt[5]{12}$

更
$1 \mathrm{P}-0.22 \mathrm{ng} / \mathrm{cm}^{2} \mathrm{C}$

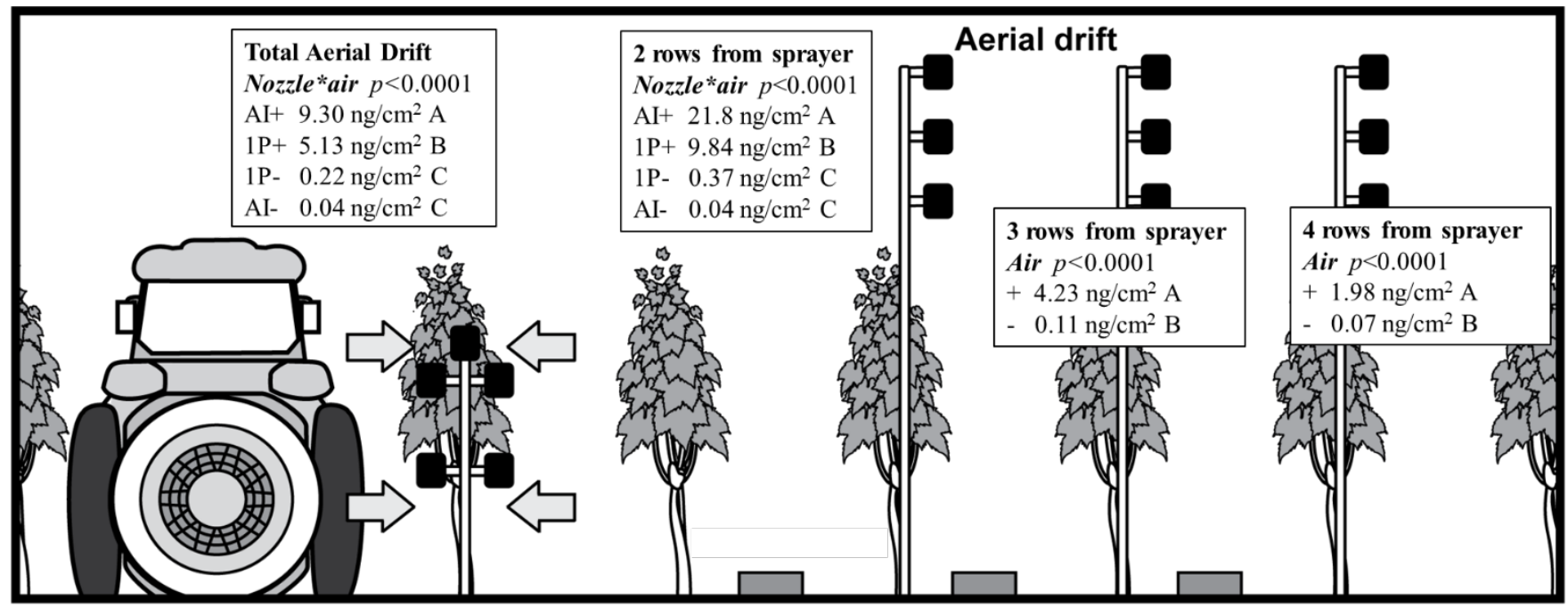

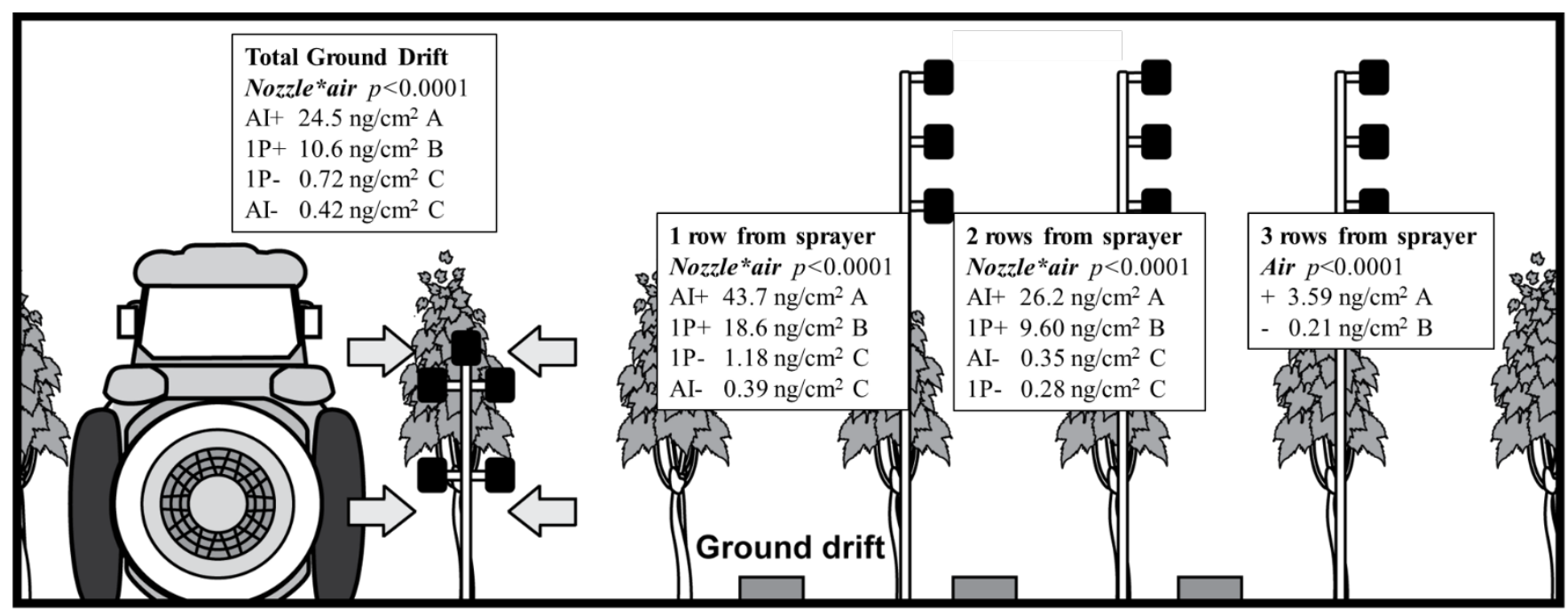

Figure 6. Mid-season ground deposition collected in rows one, two and three from the sprayed row for Rears Manufacturing Pul Blast airblast sprayer during trials in 2018 and 2020. Arrows indicate that spray occurred on both sides of the canopy. Lettering after reported average deposition (nanograms per centimeter $\left.{ }^{2}, \mathrm{ng} / \mathrm{cm}^{2}\right)$ indicate significant difference in means using Tukey's HSD at $\alpha=0.05$ within each canopy zone. $\mathrm{AI}=$ air induction nozzle; $1 \mathrm{P}=$ one-piece nozzle; + = with air-assistance; - = without airassistance. Only effects that were statistically significant are shown. 
Catalyst Papers in Press are peer-reviewed, accepted articles that have not yet been edited or formatted, but may be cited by DOI. The final version may contain substantive or nonsubstantive changes.

discovery into practice

doi: 10.5344/catalyst.2021.21001

504

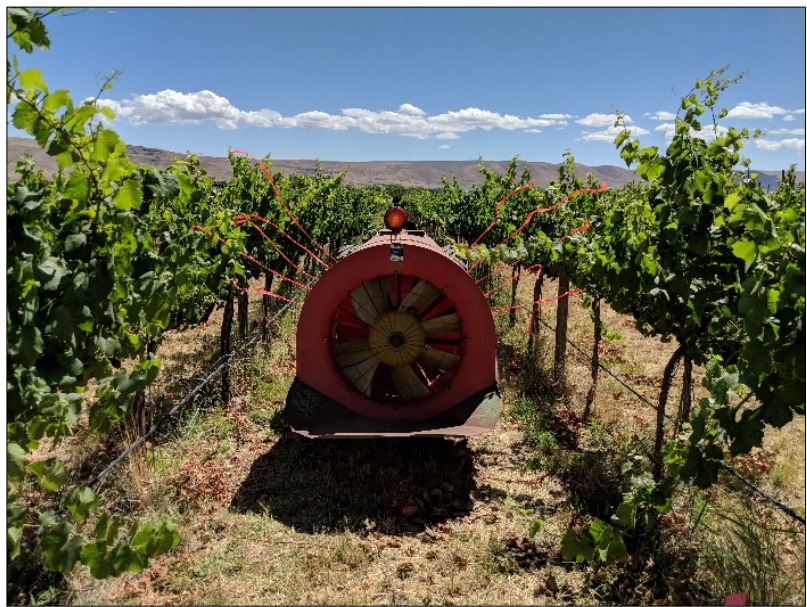

505

506

507

508

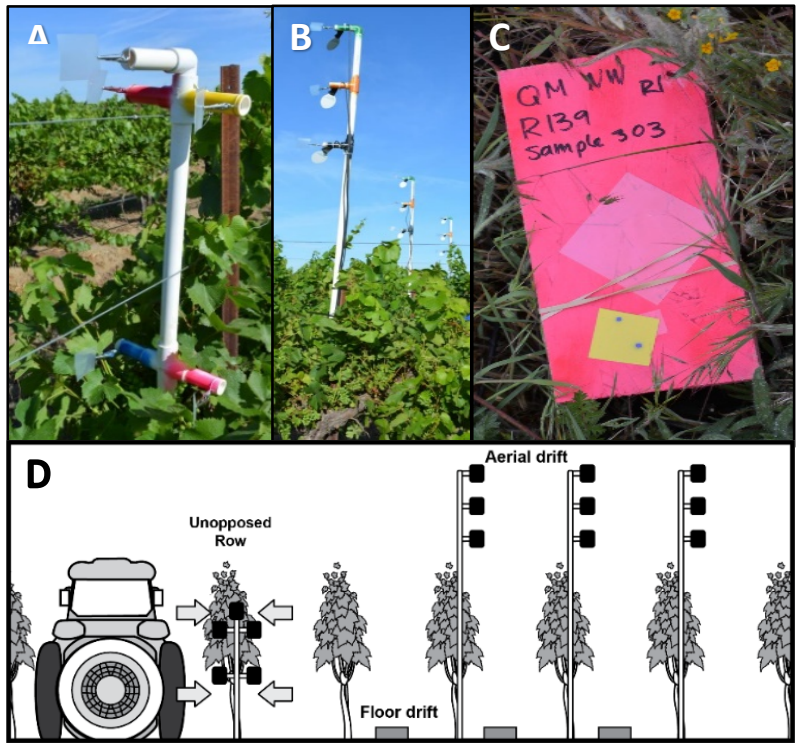

Figure 7. Evaluation of different optimization techniques such as the type of nozzle and the use of air-assistance on a Rears Manufacturing Pul Blast airblast sprayer. The trials were conducted between 2018 and 2020 in the Yakima Valley AVA of Washington State.

Figure 8. A series of different collection techniques, as described in McCoy et al. (2021), were deployed in this trial. (A) Canopy deposition was collected using an in-canopy set-up that had spray card collectors across 5 different canopy zones; (B) Captured aerial drift was collected at three heights above the canopy, and in two to four rows from the sprayed row; and (C) Ground deposition was collected on wooden blocks in the first three rows from the sprayed row. (D) This is a general representation of the deposition and drift collection approach for this experiment.

515 Figure 8D by Charlotte Oliver, Washington State University. 
Catalyst Papers in Press are peer-reviewed, accepted articles that have not yet been edited or formatted, but may be cited by DOI. The final version may contain substantive or nonsubstantive changes.

Table 1. Operational parameters of the Rears Manufacturing Pul Blast airblast sprayer used in the Washington state trials between 2018 and 2020. Day of year (DOY) from 1 January.

\begin{tabular}{|c|c|c|c|c|c|c|}
\hline Year & $\begin{array}{l}\text { Application } \\
\text { Timing }\end{array}$ & Nozzle type & $\begin{array}{l}\text { DOY (vine } \\
\text { growth stage- } \\
\mathrm{BBCH})^{\mathrm{b}}\end{array}$ & $\begin{array}{c}\text { Tractor travel } \\
\text { speed } \\
(\mathrm{km} / \mathrm{h} / \mathrm{MPH})\end{array}$ & $\begin{array}{l}\text { Application } \\
\text { water volume } \\
\text { (LPH / GPA) }\end{array}$ & $\begin{array}{l}\text { Engine } \\
\text { Speed } \\
\text { (RPM) }\end{array}$ \\
\hline \multirow[b]{2}{*}{2019} & \multirow{4}{*}{ Early } & $\begin{array}{c}\text { Teejet }^{\mathbb{B}} \text { VisiFlo }^{\circledR} \\
\text { TX-VK12 }\end{array}$ & $143 \& 144$ & \multirow{4}{*}{$5.3 / 3.3$} & \multirow{4}{*}{$233.9 / 25$} & \multirow{4}{*}{1900} \\
\hline & & $\begin{array}{l}\text { Teejet }^{\circledR} \text { AITX- } \\
8002 \text { VK }\end{array}$ & (57) & & & \\
\hline \multirow{2}{*}{2020} & & $\begin{array}{c}\text { Teejet }^{\mathbb{R}} \text { VisiFlo }^{\circledR} \\
\text { TX-VK12 }\end{array}$ & \multirow{2}{*}{$\begin{array}{c}140 \& 147 \\
(57)\end{array}$} & & & \\
\hline & & $\begin{array}{c}\text { Teejet }^{\circledR} \text { AITX- } \\
8002 \text { VK }\end{array}$ & & & & \\
\hline \multirow{2}{*}{2018} & \multirow{4}{*}{ Mid } & $\begin{array}{c}\text { Teejet }^{\circledR} \text { VisiFlo } \\
\text { TX-VK12 } \\
\end{array}$ & \multirow{2}{*}{$\begin{array}{l}194 \& 198 \\
\quad(77)\end{array}$} & \multirow{2}{*}{$3.7 / 2.3$} & \multirow{4}{*}{$467.7 / 50$} & \multirow{2}{*}{1800} \\
\hline & & $\begin{array}{c}\text { Teejet }^{\circledR} \text { AITX- } \\
8002 \text { VK }\end{array}$ & & & & \\
\hline \multirow{2}{*}{2020} & & $\begin{array}{c}\text { Teejet }^{\mathbb{B}} \text { VisiFlo } \\
\text { TX-VK18 }\end{array}$ & \multirow{2}{*}{$\begin{array}{c}193 \& 196 \\
\quad(77)\end{array}$} & \multirow{2}{*}{$5.3 / 3.3$} & & \multirow{2}{*}{1900} \\
\hline & & $\begin{array}{l}\text { Teejet }^{\mathbb{B}} \text { AITX- } \\
8003 \mathrm{VK}\end{array}$ & & & & \\
\hline
\end{tabular}


Catalyst Papers in Press are peer-reviewed, accepted articles that have not yet been edited or formatted, but may be cited by DOI. The final version may contain substantive or nonsubstantive changes.

Table 2. The sprayer configurations, weather, day of year (DOY), and canopy volume during the early season application experiment conducted using Rears Manufacturing Pul Blast airblast sprayer in Washington state optimization trials between 2019 and 2020.

\begin{tabular}{|c|c|c|c|c|c|c|c|}
\hline Year & $\begin{array}{l}\text { Application } \\
\text { experiment }\end{array}$ & $\begin{array}{l}\text { Nozzle and air } \\
\text { treatment }\end{array}$ & $\begin{array}{l}\text { Avg } \\
\text { temp } \\
\left({ }^{\circ} \mathrm{C}\right)\end{array}$ & $\begin{array}{l}\text { Avg relative } \\
\text { humidity }(\%)\end{array}$ & $\begin{array}{l}\text { Avg wind } \\
\text { speed } \\
(\mathrm{km} / \mathrm{h})\end{array}$ & $\begin{array}{c}\text { Avg wind } \\
\text { direction }\left({ }^{\circ}\right)^{\mathrm{a}}\end{array}$ & $\begin{array}{l}\text { Vine-row- } \\
\text { volume } \\
\left(\mathrm{m}^{3} / \mathrm{ha}\right)\end{array}$ \\
\hline \multirow{8}{*}{2019} & \multirow{4}{*}{1} & 1-piece, air on & 17.9 & 74.9 & 4.2 & *W (261) & \multirow{8}{*}{850.7} \\
\hline & & 1-piece, air off & 18.7 & 78.1 & 4.3 & $* \mathrm{~S}(170)$ & \\
\hline & & $\mathrm{AI}$, air on & 19.4 & 75.0 & 5.9 & $* \mathrm{~N}(10.8)$ & \\
\hline & & AI, air off & 19.1 & 72.9 & 7.5 & $* \mathrm{~S}(171)$ & \\
\hline & \multirow{4}{*}{2} & 1-piece, air on & 13.3 & 82.0 & 6.5 & WNW (283) & \\
\hline & & 1-piece, air off & 13.7 & 82.7 & 9.8 & W (281) & \\
\hline & & AI, air on & 19.1 & 61.1 & 3.8 & ESE (103) & \\
\hline & & AI, air off & 15.8 & 78.3 & 2.3 & ENE (62) & \\
\hline \multirow{8}{*}{2020} & \multirow{4}{*}{3} & 1-piece, air on & 11.2 & 85.1 & 6.8 & W (270) & \multirow{8}{*}{596.2} \\
\hline & & 1-piece, air off & 11.4 & 86.8 & 14.7 & SW (221) & \\
\hline & & AI, air on & 11.7 & 88.4 & 19.1 & WSW (241) & \\
\hline & & AI, air off & 11.5 & 88.5 & 16.9 & SW (228) & \\
\hline & \multirow{4}{*}{4} & 1-piece, air on & 15.1 & 72.2 & 2.4 & *NW (325) & \\
\hline & & 1-piece, air off & 16.7 & 68.4 & 2.6 & *S (191) & \\
\hline & & AI, air on & 18.6 & 58.8 & 9.6 & *SW (236) & \\
\hline & & AI, air off & 16.7 & 63.8 & 6.5 & *SW (236) & \\
\hline \multicolumn{8}{|c|}{$\begin{array}{l}\text { a Early season collections occurred on DOY } 143 \text { and } 144 \text { in } 2019 \text { and DOY } 140 \text { and } 147 \text { in } 2020 \text {. Weather } \\
\text { data were collected from an on-site ATMOS weather station for DOY } 144 \text { and 140, and from Washington } \\
\text { State University AgWeatherNet (weather.wsu.edu) "Prosser NE" station, located within } 1000 \text { m of the } \\
\text { site, and an elevation difference of less than } 50 \mathrm{~m} \text {. as noted with an *). }\end{array}$} \\
\hline
\end{tabular}


Catalyst Papers in Press are peer-reviewed, accepted articles that have not yet been edited or formatted, but may be cited by DOI. The final version may contain substantive or nonsubstantive changes.

Table 3. The sprayer configurations, weather, day of year (DOY), and canopy volume during the midseason application experiment conducted using Rears Manufacturing Pul Blast airblast sprayer in Washington state optimization trials between 2018 and 2020.

\begin{tabular}{|c|c|c|c|c|c|c|c|}
\hline Year & $\begin{array}{l}\text { Application } \\
\text { experiment }\end{array}$ & $\begin{array}{l}\text { Nozzle and air } \\
\text { treatment }\end{array}$ & $\begin{array}{c}\text { Avg } \\
\text { temp } \\
\left({ }^{\circ} \mathrm{C}\right)\end{array}$ & $\begin{array}{l}\text { Avg relative } \\
\text { humidity }(\%)\end{array}$ & $\begin{array}{l}\text { Avg wind } \\
\text { speed } \\
(\mathrm{km} / \mathrm{hr})\end{array}$ & $\begin{array}{c}\text { Avg wind } \\
\text { direction }\left({ }^{\mathrm{o}}\right)^{\mathrm{a}}\end{array}$ & $\begin{array}{l}\text { Vine-row- } \\
\text { volume } \\
\left(\mathrm{m}^{3} / \mathrm{ha}\right)\end{array}$ \\
\hline \multirow{8}{*}{2018} & \multirow{4}{*}{1} & 1-piece, air on & 15.7 & 67.0 & 13.3 & NW (321) & \multirow{8}{*}{$2,056.1$} \\
\hline & & 1-piece, air off & 17.3 & 67.4 & 9.1 & NNW (335) & \\
\hline & & AI, air on & 24.2 & 55.5 & 8.1 & SSE (158) & \\
\hline & & AI, air off & 22.1 & 58.6 & 2.3 & $\mathrm{~S}(171)$ & \\
\hline & \multirow{4}{*}{2} & 1-piece, air on & 18.0 & 61.3 & 11.4 & WSW (237) & \\
\hline & & 1-piece, air off & 19.0 & 56.0 & 10.2 & WSW (247) & \\
\hline & & AI, air on & 23.1 & 47.3 & 7.6 & NNW (330) & \\
\hline & & AI, air off & 21.2 & 52.1 & 5.9 & WNW (287) & \\
\hline \multirow{8}{*}{2020} & \multirow{4}{*}{3} & 1-piece, air on & 12.2 & 75.0 & 10.9 & NNW (334) & \multirow{8}{*}{$2,486.3$} \\
\hline & & 1-piece, air off & 16.2 & 65.2 & 5.7 & WNW (293) & \\
\hline & & AI, air on & 19.9 & 56.7 & 12.4 & SSE (156) & \\
\hline & & AI, air off & 18.1 & 59.8 & 4.3 & $\mathrm{~W}(271)$ & \\
\hline & \multirow{4}{*}{4} & 1-piece, air on & 11.1 & 62.3 & 11.8 & $\mathrm{~N}(351)$ & \\
\hline & & 1-piece, air off & 14.4 & 56.9 & 8.1 & $\mathrm{~N}(351)$ & \\
\hline & & AI, air on & 18.8 & 46.0 & 7.2 & W (276) & \\
\hline & & AI, air off & 18.0 & 50.5 & 6.1 & SW (226) & \\
\hline
\end{tabular}

